\title{
The Tartu Peace Treaty of FEBRUARY 1920 AND ITS AFTERMATH: A CASE FOR RUSSIAN-ESTONIAN CONCILIATION (A CONTEMPORARY VIEW FROM RUSSIA)
}

\author{
Konstantin Khudoley
}

The First World War and the revolutions in Russia, Germany, and Austria-Hungary, as a result of which the three empires collapsed, the disintegration of the Ottoman Empire and the rise of national movements in China, India and a few other countries all led to fundamental socio-political changes around the world. ${ }^{1}$ Their effect was particularly dramatic for Central and Eastern Europe, where a group of new states emerged. Their progress towards independence was spurred by certain external factors such as the Soviet government's first decrees (the Decree on Peace, and the Declaration of the Rights of the Peoples of Russia) and 'The Fourteen Points' of US President Woodrow Wilson. The Decree made the claim for peace without annexations and contributions ${ }^{2}$ and the Declaration proclaimed the rights of nations to self-determination until separation and the creation of an independent state ${ }^{3}$. The purpose of the Bolsheviks was to destabilise the capitalist system and create more favourable conditions for the triumph of the socialist revolution. Moreover, Vladimir Lenin put the interests of the socialist republic above the right of nations to self-determination. ${ }^{4}$ Meanwhile, 'The Fourteen Points' focused primarily, though

\footnotetext{
1 Pervaya mirovaya voìna i sud' by evropeiskoĭ civilizaciŭ, ed. by L. S. Belousova, A. S. Manykina (Moskva: MGU, 2014); Aleksey I. Miller, "Pochemu vse kontinentalnie imperiı̌ raspalis' v rezultate Peroĭ mirivoŭ voĭnȳ", <URL: https://polit.ru/article/2006/o4/11/ miller2>, 25 October 2020; Michael A. Reynolds, Shattering Empires: The Clash and Collapse of the Ottoman and Russian Empires 1908-1918 (Cambridge: Cambridge University Press, 2011).

2 Vladimir I. Lenin, "Dekret o mire”, Polnoe sobranie sochineniŭ, Vol. 35 (Moskva: Izdatel `stvo politicheskoı̆ literaturȳ, 1974), 13.

3 Deklaraciya prav narodov Rossii, Dekrety sovetskoŭ vlasti, Vol. 1 (Moskva: Gospolitizdat, 1957), 40.

4 Vladimir I. Lenin, "O revolucionnoĭ fraze”, Polnoe sobranie sochineniŭ, Vol. 35 (Moskva: Izdatel `stvo politicheskoí literaturȳ, 1974), 352.
} 
not exclusively, on Europe and comprised quite specific propositions. ${ }^{5}$ The assumption was that their implementation would facilitate the spread of democracy and free trade around the world and keep Bolshevism at bay. Yet, despite their differences, Soviet Russia, and the USA both drew on the premise of the right of nations to self-determination, including the right to secession. This was turning the right to self-determination into one of the basic principles of world politics.

The 1919 Peace Treaty of Versailles and the other treaties signed at the Paris Peace Conference only partially resolved the outstanding problems of the post-war world order - the global economy was still in decline, domestic political struggles in most countries intensified exponentially, the amount of German reparations was not determined, and newly emerged states were set against great powers, as well as against each other. ${ }^{6}$ It would take a few more years to attain relative stability, during which time a number of new treaties were concluded. Among these, the Soviet-Estonian Peace Treaty signed in Tartu on 2 February 1920 took pride of place as the first peace treaty between a socialist power and a small capitalist state. Unlike the Brest-Litovsk Peace Treaty of 1918, when the German Empire and its allies could dictate their conditions to Soviet Russia, this time the Soviet government could demonstrate just how far it was willing to go in the realisation of the right of nations to self-determination. The recognition of Finnish independence in December of 1917 was not a precedent either because at that stage, the Bolsheviks were sure of the quick victory of socialist revolution, although the German position on Finland at the peace negotiations in Brest-Litovsk also influenced the Soviet government's decision.?

Both Soviet and Russian academic literature on the Tartu Peace Treaty and the consequent Soviet-Estonian relations is far from extensive. In the 1920 s and 1930s, it was a question of propaganda rather than genuine research. For several decades afterwards, the topic was either silenced or mostly reduced to meaningless vacuities. Thus, in all the official publications

Thomas Woodrow Wilson's 'The Fourteen Points' Message to Congress, 8 January 1918, Address of the President (H. Doc. No. 765), (Congressional Record, 8 January 1918), 690-693.

$6 \quad$ Margaret MacMillan, Paris 1919: six months that changed the world (New York: Random House, 2003); Voinna, revoluciya, mir. Rossiya v mezhdunarodnikh otnosheniyakh 1915-1925 (Moskva: Aspekt-press publ., 2019); Anatolij V. Smolin, U zakritikh dvere Versalskogo dvorca. Parizhskaya mirnaya konferenciya i russkaya diplomatiya $v 1919 \mathrm{~g}$. (Sankt - Peterburg: Nauka, 2017).

7 Irina N. Novikova, "Finskaya karta" v nemeckom pasyanse. Germaniya i problema nezavisimosti Finlyandii v godi Piervol̆ mirovoĭ voĭny (Sankt - Peterburg: SPbGU, 2002), $180-197$. 
on the history of the Communist Party - from Stalin's History of the AllUnion Communist Party (Bolsheviks). Short Course 8 (1938) to the multivolume History of the Communist Party of the Soviet Union (1986), these questions were not mentioned at all. ${ }^{9}$ The multivolume History of the USSR (1967) stated that the borders established by the treaties of 1920-1921 were 'largely in violation of long-standing territorial homogeneity', whereas 'the transient victory of the bourgeoisie in Estonia, Latvia and Lithuania had cut the republics off from the other republics of the Soviet country'. ${ }^{10}$ Only the History of Foreign Policy of the USSR described the 1920 treaty with Estonia as 'a solid victory for the Soviet state's foreign policy'. ${ }^{11}$ From the 1960 os through the 1980s, similar judgements were commonly made in publications dedicated to the initial steps of Soviet diplomacy on the international stage. What made Soviet literature distinct was that developments in Estonia and the Tartu Peace Treaty were treated solely in the context of the Civil War and foreign intervention in the outskirts of the former Russian Empire, while the national ambitions of the Estonian people were practically never mentioned.

In the post-communist years, Russian research experienced a major shakeup, affecting the study of those subjects as well. The number of scholars studying Estonia and its relations with the USSR and Russia increased. As a result of the release of new documents and the partial opening of archives, the source base expanded considerably and contacts with Estonian and other international researchers were established. The monopoly of Marxist-Leninist methods of approaching social sciences eroded, giving way to elements of pluralism of opinion. Yet, the differences between Russian scholars and their Western counterparts continued to run along the lines of political views rather than theoretical or methodological approaches. Currently, three main trends can be loosely identified. The first one encompasses those who entirely condone Soviet policy towards Estonia, using a wide range of arguments from the Soviet era. The second consists of a large number of scholars who are generally sympathetic towards Soviet policy, however, they employ a completely different set of arguments emphasising raison d'etat as they understand it. Finally, a few

\footnotetext{
$8 \quad$ Istoriya Vsesouznoĭ Kommunisticheskoĭ Partii (Bolshevikov). Kratkiy kurs (Moskva: Gospolitizdat, 1938).

9 Istoriya Kommunisticheskoĭ partii Sovetskogo Soyuza. Vol. III. 1918-1922 (Moskva: Politizdat, 1986).

$10 \quad$ Istoriya SSSR $s$ drevně̌shikh vremën do nashikh dně̆. Seria 2. Vol. 8 (Moskva: Nauka, 1967), 21.

11 Istoriya vneshne ı̆ politiki SSSR, Vol. I. 1917-1945 (Moskva: Nauka, 1980), 111.
} 
scholars are critical of Soviet policy, agreeing partially or in full with the views of international and particularly Estonian scholars. Obviously, these trends are still in their formative stages, hence no clear lines can be drawn between them.

The research problem studied in this paper is to demonstrate the significance of the Tartu Peace Treaty of February, 1920 as a case of mutually beneficial compromise between a great power and a small country with antagonistic social-political systems, and the importance of this methodology for attempts to find Russian-Estonian reconciliations in this century.

\section{'A New Brest' or Temporary Stability?}

There had always been two lines present in the foreign policy of the Soviet state. The first one was a course for World Revolution. The Bolshevik Party programme adopted at the VIII Congress (1919) proclaimed 'the onset of an era of the world proletarian communist revolution..' The CPSU programme (1961) continued to speak of 'the world socialist revolution', 'the world revolutionary process', 'the epoch of the victory of socialism and communism on a world-wide scale, ${ }^{13}$ etc. Even in its new edition (1986), the programme stated that the October Revolution was the start of an irreversible process of change from capitalism to the communist social economic formation. ${ }^{14}$ These ideas were practically always presented in official Communist Party documents and propaganda. ${ }^{15}$ It was only at the XIX CPSU conference (1988) that the Soviet leader Mikhail Gorbachev proclaimed the priority of human values over class values and all mention of the 'victory of communism' disappeared. ${ }^{16}$

\footnotetext{
12 Kommunisticheskaya partiya Sovetskogo Soyuza v rezolyuciyakh i resheniyakh s"ezdov, konferenciü i plenumov CK. Izdanie 9. Vol. II (1917-1922) (Moskva: Politizdat, 1983), 71.

${ }_{13}$ Kommunisticheskaya partiya Sovetskogo Soyuza $w$ rezolyuciyakh i resheniyakh s"ezdov, konferenciu i plenumov CK. Izdanie 9. Vol. X (1961-1965) (Moskva: Politizdat, 1986), 83.

14 XXVII S'ezd Kommuisticheskoy Partii Sovetskogo Souza. 25 fevralya - 6 marta 1986. Stenograficheskii otchet. Vol. 1 (Moskva: Politizdat, 1986), 557.

$15 \quad$ Konstantin K. Khudoley, "Evoluciya idei mirovoy revolucii v politike Sovetskogo Soyuza (epokha kominterna i socializma vodnoy strane)", Vestnik Sankt-Peterburgskogo Universiteta. Politologia. Mezhdunarodnȳe otnosheniya, 2 (2017), 145-165; Konstantin K. Khudoley, "Evoliciya idei mirovoy revolucii v politike Sovetskogo Soyuza (podjem i raspad mirovoi sistemy socializma)", Vestnik Sankt-Peterburgskogo Universiteta. Politologia. Mezhdunarodnȳe otnosheniya, 1 (2018), 53-85.

16 XIX Vsesouznaya konferenciya Kommunisticheskoi partii Sovetskogo Souza. 28 iunya - 1 iulya 1988. Stenograficheskii otchet. Vol 1 (Moskva: Politizdat, 1988), 41.
} 
The second line was a course for peaceful coexistence with the capitalist system since, as noted by Vladimir Lenin, a socialist republic could not escape economic agreements to coexist with imperialist powers except in the case of moving out to the Moon. ${ }^{17}$ That said, peaceful coexistence was initially thought of as a brief respite between wars and revolutions, and then as a 'specific form of class struggle'.$^{18}$ Only in the late 1980 os did Mikhail Gorbachev proclaim that ideological differences should not affect relations between states. ${ }^{19}$

At first, following the 1917 October Revolution, the line of world revolution dominated. In March of 1919, shortly after the establishment of the Communist International, the latter's head, Grigory Zinoviev, asserted that it would take just a year for the whole of Europe to turn communist. ${ }^{20}$ However, with the defeat of the Soviet republics in Hungary (August 1919) and Bavaria (May 1919), and with the country having suffered heavy casualties in the Civil War, the Soviet government's policy started drifting towards the line of peaceful coexistence.

Like most other new states, Estonia found itself in dire circumstances. The Bolsheviks were trying to re-assert control after the end of the German occupation, having proclaimed the Estonian Workers' Commune headed by Jaan Anvelt. Most Estonians rejected it and a few months later it practically ceased to exist, yet the fighting against the Red Army continued.

The chief commanders of the White movement - Alexander Kolchak and Anton Denikin - flatly refused to recognise Estonia's independence. This was done only by the government of the North-West, the political influence of which was rather limited. But even in the North-west, there was no unity among the Whites - General Nikolai Yudenich's negative attitude towards Estonian independence was not a secret. ${ }^{21}$ Neither was the Entente in a hurry to recognise Estonia's independence due to both the stance taken by the leaders of the White movement and the disagreements

\footnotetext{
17 Vladimir I. Lenin, Polnoe sobranie sochineniŭ, Vol. 35 (Moskva: Izdatel 'stvo politicheskoĭ literaturȳ, 1974), 402.

18 Kommunisticheskaya partiya Sovetskogo Soyuza $v$ rezolyuciyakh i resheniyakh s"ezdov, konferenciǔ i plenumov CK, Izdanie 9. Vol. X (1961-1965). (Moskva: Politizdat, 1986), 123-124.

19 Mikhail S. Gorbachev, Perestrŏka i novoje politicheskoe mishlenie dla nashej strani i vsego mira (Moskva: Politizdat, 1987), 146.

20 Griroriŭ E. Zinov`ev, "Perspektivȳ mirovoŭ revolyucii”, Kommunisticheskiŭ internacional, 1919, №1, 42.

21 Mikhail I. Meltukhov, Pribaltiǔskiǔ platsdarm v politike Moskvi (1918-1939) (Moskva: Algoritm, 2015), 141; Anatolǐ V. Smolin, Beloe dvizhenie na Severo-Zapade Rossii (1918-1920) (Sankt-Peterburg: Dmitrij Bulanin, 1999), 169.
} 
among its allies. Meanwhile, international recognition was vital for Estonia in order to return to a peaceful life, to overcome economic chaos and, perhaps, to obtain assistance from other countries. Therefore, Moscow and Tallinn started finding some common ground, prompting them to start negotiations. The latter proceeded for several months with lots of difficulties. Nonetheless, by early 1920 a peace treaty had been drafted and was ready to be signed.

There were probably several reasons why the Soviet government decided to start peace negotiations with the Estonian government. First, in 1919, despite a number of successful Red Army operations on the fronts of the Civil War, the overall situation presented an extremely daunting challenge. Hostilities against the White Army continued in Siberia and the Far East (where Japanese troops were also stationed), in the south of Russia, and against Poland. In the context of the policy course aimed at world revolution, it was the war with Poland that was of particular significance for the Bolsheviks. ${ }^{22}$ Despite the defeat of Yudenich's army, the situation in the northwest, including around Petrograd - an important political, economic, and cultural centre that had been the capital of Russia for almost two centuries - remained tense. The signing of a peace treaty with Estonia allowed the Bolsheviks to consolidate their power in north-western Russia and to re-allocate resources for the war with Poland. According to some contemporary Russian historians, this was precisely one of the motives why Moscow opted to quickly sign a peace treaty with Estonia, and somewhat later with Latvia and Lithuania. ${ }^{23}$ However, it is most likely that economic and political factors played an even greater role in the Soviet government's decision to conclude a peace treaty with Estonia.

Secondly, Russia's economy had been almost entirely ruined by the Civil War, in particular by the policy of War Communism aimed at eliminating market relations. The population's living standards plummeted precipitately, while some regions experienced hunger. Soviet Russia's foreign trade turnover was at its lowest. Foreign governments, businesses and publics were outraged at Russia for signing the separate Peace Treaty of Brest-Litovsk, as well as at the Bolshevik nationalisation of Russian and foreign-owned enterprises without any compensation, the refusal to honour the debts of the tsarist and Provisional governments (these were unprecedented acts in the history of modern times), and at the repressions against foreign

22 Artem V. Barynkin, Irina N. Novikova, "Polskiǔ vopros i proletarskiǔ internatsionalizm v sovietskoĭ vneshneĭ politike na rubezhe 1918-1919 gg", Voprosȳ istorii, 8 (2020), 153-165.

23 Voĭna, revoluciya, mir, 182. 
nationals. At the same time, U.S. and especially European publics were showing signs of extreme weariness as a result of their suffering the ravages of war. In January of 1920, the Supreme Council of the Entente decided to lift the blockade against Soviet Russia. However, the decision was not a recognition of the Soviet government, and bans and limitations on trade with Soviet Russia, introduced by national governments, were still in force. For this reason, the Bolsheviks wanted as soon as possible to gain access to at least one official channel for procuring needed supplies. A peace treaty with Estonia could open the way to such a channel.

Thirdly, by signing a peace treaty with Estonia, Soviet Russia pursued a more far-reaching goal - that of launching dialogue on normalising relations with the leading Western nations. Moscow was perfectly aware that rising pacifism was inhibiting a prolonged military intervention, and that the ongoing economic crisis was giving a voice to those Western business leaders who wanted to restore trade with Russia. It was also known that some serious disagreements had emerged within the British Cabinet between Prime Minister David Lloyd George, who was in favour of normalising relations, and the Conservatives, who advocated a more hard-line approach. The Soviet government decided to take advantage of all those factors and to make the treaty with Estonia a pilot case to demonstrate that Soviet Russia possessed the capacity to negotiate. As pointed out by the People's Commissar for Foreign Affairs Georgy Chicherin, the original rationale behind the treaty with Estonia was to secure the western flank; however, that rationale later expanded significantly, so much so that those negotiations became a sort of 'dress rehearsal' for a deal with the Entente. ${ }^{24}$

According to the treaty of 1920, Soviet Russia and Estonia were declaring the end of the state of war (Article I) and their desire to establish diplomatic and consular relations (Article XV). ${ }^{25}$ This was a resounding success for Estonian diplomacy because until then, the Soviet government had not officially recognised the hostilities as warfare between two countries. At the same time, on the basis of the declared right of nations to selfdetermination, including the right to secession, Soviet Russia unconditionally recognised the independence of the Estonian state, and voluntarily renounced in perpetuity all sovereign rights formerly held by Russia in

\footnotetext{
24 Georgiı̌ V. Chicherin, Stat' i i rechi po voprosam mezhdunarodnoǐ politiki (Moskva: Socekgiz, 1961), 135.

25 "Mirnȳı̆ dogovor mezhdu Rossieй i Estonieŭ. 2 fevralya 1920", Dokumentȳ vneshně politiki SSSR. Vol. II. 1 yanvarya 1919 - 30 iyunya 1920 (Moskva: Gospolitizdat, 1958), 340, 350 .
} 
relation to the Estonian people and land (Article II) ${ }^{26}$ Thus, the independence proclaimed in the Manifest Eestimaa rahvastele on 24 February 1918 was internationally recognised for the first time. Likewise, Moscow could not be regarded as the losing party since the treaty made direct reference to the right of nations to self-determination proclaimed by the Soviet government. Wilson's 'Fourteen Points' did have some impact on creating a general atmosphere conducive to the treaty, although there was no direct mention of those points in the treaty.

The peace treaty established a state border that roughly coincided with the front line. Almost all Russian historians assess that decision negatively. They see it as a kind of fee paid to Estonia for its consent not to support the White movement. ${ }^{27}$ Furthermore, it should be added that Lenin thought it possible in principle to make territorial concessions to neighbouring states so as to advance the future Soviet revolution in them. In July of 1920, he wrote about this in relation to Poland. ${ }^{28}$ It is quite possible, however, that he had been guided by similar ideas during the preparatory period for signing the peace treaty with Estonia. It should also be borne in mind that the Bolsheviks viewed all state borders as temporary, for they were certain that the World Republic of the Soviets would be forthcoming shortly.

The treaty placed considerable emphasis on non-interference in each other's internal affairs and on some security issues. Thus, both parties undertook to prohibit the presence in their respective territory of any troops other than their own or those of friendly states, provided that the state in question was not at war with the other contracting party, to prevent soldiers and the command staff of dissident armed forces from enlisting under any kind of pretext, including as volunteers, in the government forces of the contracting parties, and to prevent the establishment and presence in their territory of missions and groups of representatives aiming to overthrow the other contracting party's government. Some restrictions were also imposed on military activity in the border areas and waters. Regarding international recognition of Estonia's permanent neutrality, Russia undertook to respect it and to participate in the relevant guarantees (Articles V, VI, VIII). ${ }^{29}$ Those provisions of the treaty were only partially

\footnotetext{
26 Ibid., 340.

27 Nikolă M. Mezhevich, "Rossiǔsko-estonskaya granitsa: istoriya formirovaniya i sovremennoe znachenie dla razvitiya Severo-Zapada Rossii”, Pskovskiŭ regionalisticheskiu zhurnal, 4 (2007), 140.

28 Vladimir I. Lenin, “Telegramma I. S. Unshlikhtu 15 ijulya 1920 g.", Lenin V. I. Neizvestnye dokumenty (Moskva: ROSPEN, 2017), 354.

29 "Mirnȳĭ dogovor mezhdu Rossieŭ i Estonieŭ. 2 fevralya 1920", 342, 345.
} 
implemented. Estonia, albeit belatedly, stopped supporting the activities of White troops in its territory. Estonian communists, using the territory of the Soviet Union, continued to pursue their efforts in preparing for a revolution. Although the organisational architecture was somewhat modified, their efforts were still financed almost entirely by the Soviet government. There were also cases of 'Red Estonians' joining the ranks of the Red Army. In this manner, following the liquidation of the Estonian Workers' Commune, Anvelt served in the Red Army from 1919 to 1921 and engaged in clandestine activity in Estonia from 1921 to 1925. Following the collapse of the communist coup attempt in Estonia in December of 1924, he fled back to the Soviet Union, holding various posts in the Red Army and the Comintern. The failure to fulfil obligations resulting from the treaty in such an important and sensitive matter, primarily on the part of the Soviet Union, made it much more difficult to realise the treaty's positive potential in other areas.

The treaty provided for a settlement of mutual claims and for taking steps towards developing trade and economic relations. Initially, the Soviet delegation contended that as a general principle, if a state emerged from an existing one, the former would not be paid, but rather had to pay the latter. In the course of negotiations, however, the Soviet side agreed to waive all payments and then made further concessions. ${ }^{30}$ Thus, Estonia was to receive 15 million roubles in gold and all Russian property located in its territory, and was completely exempt from any financial obligations arising from being part of tsarist Russia. Both parties agreed to abandon all mutual claims and grant each other most-favoured-nation status, including with regard to importing and exporting goods to each other's territory (neither export duties nor transit taxes were to be charged). In Reval and other free ports of Estonia, Russia was supposed to gain access to stations on preferential terms for transit shipment, storage and repacking of goods coming from destined for Russia. The parties agreed to grant concessions to each other in their territories (Articles XI, XII, XIII, XVI)..$^{31}$ According to the prominent Soviet diplomat Ivan Maisky, 'it was a bit expensive', but since Estonia happened to be the first country to enter into an agreement with Soviet Russia, it needed 'an expected compensation for the risk' and 'we had to go the extra mile.".

\footnotetext{
30 Godovorotchet NKID k VIII s'ezdu Sovetov (1919-1920) (Moskva, 1921), 13.

31 "Mirnȳĭ dogovor mezhdu Rossieŭ i Estonieŭ. 2 fevralya 1920", 347, 350.

32 Ivan M. Majskiŭ, Vneshnyaya politika R.S.F.S.R. 1917-1922 (Moskva: Krasnaya nov', 1923), 8 o.
} 


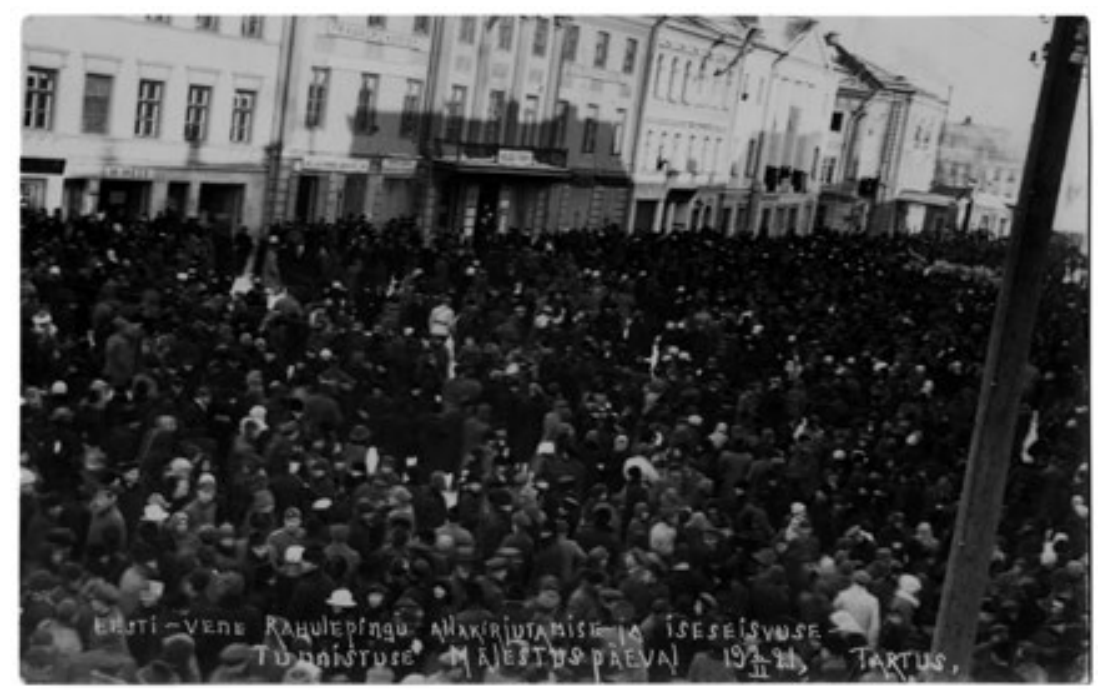

Figure 1. Celebrations marking one-year anniversary of the Tartu Peace Treaty. People gathering in the Town Hall Square in Tartu, February 2, 1921. Estonian National Archives (RA), EAA.2073.1.21.1

Thus, all in all, the Tartu Peace Treaty was a sensible and mutually beneficial compromise. It was significant not only because it ended hostilities across a compact area south of the Gulf of Finland, but also because, in a way, it set a pattern for future peace treaties with Latvia, Finland and a few other countries.

Practically all Russian scholars agree that the Tartu Peace Treaty created favourable conditions for the development of the Estonian state. ${ }^{33} \mathrm{At}$ the same time, some of them (Mezhevich, ${ }^{34}$ Smolin, ${ }^{35}$ Shishkin ${ }^{36}$ ) compare the peace treaties of Soviet Russia with Estonia and Finland (Tartu, 14 October 1920) to the Treaty of Brest-Litovsk (1918). They presume that Soviet Russia made colossal financial and territorial concessions (the question of ceding territory is particularly emphasised) so as to buy time in order to

\footnotetext{
33 Sergey A. Kochegarov, Voenno-politicheskie aspekty stanovleniya nezavisimogo Estonskogo gosudarstva (Sankt-Petersburg, PhD thesis, 2018), 223, https://rusneb.ru/ catalog/o00199_000009_008708212/ (20 November 2020)

34 Mezhevich, "Rossiǔsko-estonskaya granitsa", 141.

35 Anatoliı̆ V. Smolin, Novȳ̌̆ Brest. Tartuskĭ mir Sovetskoŭ Rossii s Finlandieŭ 1920 g. (Sankt Peterburg: Evraziya, 2020), 274, 280.

36 Valeriĭ A. Shishkin, Stanovlenie vneshneı̆ politiki postrevolyutsionno ̌ Rossii (1917-1930 god) i kapitalisticheskiı̆ mir (Sankt Petersburg: Dmitriĭ Bulavin, 2002), 79.
} 
later recoup the losses. In reality, Lenin's policies in 1918 and in 1920 had both similarities and differences.

Undoubtedly, both in 1918 and 1920, the Bolsheviks' main objective was to retain power, and for that they were willing to make any concessions and resort to any manoeuvring. They did hope for a forthcoming World Revolution that would engender a completely different world order. However, whereas in 1918 the revolutionary potential in Germany and some other countries seemed very strong, by 1920 the situation had become much less promising. By then the level of Bolshevik confidence in a swift global victory had become much weaker as compared to 1918. In both cases, the Bolsheviks wanted to take advantage of a peaceful respite not only for strengthening the Red Army but also for peaceful reconstruction and solving at least some of their economic problems. The Russian economy in 1920 was in much worse shape than in 1918, hence their interest in peace was much more avid.

In the meantime, there were also important differences in how the Tartu Peace Treaty and the Treaty of Brest-Litovsk were assessed. Lenin - a staunch advocate of the latter - nevertheless believed that it was 'disgraceful' and 'humiliating. ${ }^{37}$ In contrast, he considered the treaty with Estonia a success and spoke about its 'history-making significance..$^{38}$ Indeed, he had every reason to say so. The Treaty of Brest-Litovsk, which was signed in violation of all Russia's obligations, gravely undermined the country's international standing, causing profound mistrust towards Moscow on the part of a number of states. Conversely, the peace treaty with Estonia enhanced the profile of Soviet Russia and became the first step towards ending its international isolation. The Bolsheviks themselves regarded it as a 'gateway to Europe'. ${ }^{39}$ The Treaty of Brest-Litovsk, on the other hand, provoked a huge domestic crisis, becoming one of the reasons for the outbreak of the Civil War in Russia, for the breakdown of the coalition between the Bolsheviks and the Left Socialist Revolutionaries, and for bitter infighting within the Bolshevik Party. Meanwhile, the peace treaty with Estonia caused no serious turmoil at home.

That said, the attitudes within the ruling circles of Soviet Russia towards the peace treaty with Estonia were mixed. The guiding principle of the

\footnotetext{
37 Vladimir I. Lenin, Polnoe sobranie sochineniǔ, Vol. 36 (Moskva: Izdatel'stvopoliti cheskoǔliteraturȳ, 1969), 23.

38 Vladimir I. Lenin, "Doklad o rabote VCIK I Sovnarkoma na pervoŭ sessii VCIK VII Soziva 2 fevralya 1920 g.", Polnoe sobranie sochineniŭ, Vol. 40 (Moskva: Izdatel `stvo politicheskoŭ literaturȳ, 1974), 90.

39 Majskiŭ, Vneshnyaya politika R.S.F.S.R. 1917-1922, 79.
} 
Bolsheviks regarding those documents was set out in the resolution of the VII Congress (1918), which emphasised that the Central Committee had 'the power to terminate all peace treaties with all imperialist and bourgeois states at any time, as well as to declare war on them'. ${ }^{40}$ Therefore, a great many Bolsheviks did not think of the treaty with Estonia as anything enduring. However, by that time, some novel nuances had already appeared in Lenin's position. On record he stated that Estonian workers would soon overthrow 'this power and create a Soviet Estonia which will conclude a new treaty with us'. ${ }^{41}$ However, as Chicherin later noted, Lenin was demonstrating 'unparalleled flexibility' and 'political realism' by refusing to recognise a number of ethnic Soviet governments and acknowledging the need to reckon with the bourgeois national republics appearing along the border of the Soviet Union as fait accompli, hence making concessions to them..$^{42}$ For Lenin, it seems, the Tartu Peace Treaty was a watershed moment politically.

Still, the overall strategy remained unchanged. The peace treaties signed with the neighbouring countries were to be observed for as long as political expediency required. Thus, in May of 1920, a peace treaty was signed between Soviet Russia and the Georgian Democratic Republic. ${ }^{43}$ Its terms were more advantageous for Moscow than those with Estonia. However, as soon as the situation changed in favour of the Bolsheviks (the Sovietisation of Azerbaijan and Armenia, the establishment of friendly relations with Turkey, etc.), a 'revolutionary committee' was set up in Georgia to call in the Red Army. So, the conclusion of peace treaties with Estonia, and then with Latvia, Finland, Lithuania, and Poland did not signify that the Soviet Republic became part of the Versailles system in any shape or form. It still remained adversarial. As Lenin put it in the autumn of 1920, 'the modern imperialist world is hinged on the Treaty of Versailles' ${ }^{44}$ Moreover, Poland was considered the mainstay of the entire Versailles system. It can be safely assumed that if the Red Army's 1920 Warsaw offensive had been victorious, the peace treaty with Estonia would have been just as short-lived.

$40 \quad$ Kommunisticheskaya partiya Sovetskogo Soyuza $v$ rezolyutsiyakh i resheniyakh s"ezdov, konferenciŭ I plenumov CK. Izdanie 9. Vol. II (1917-1922), 27.

41 Vladimir I. Lenin, "Rech ' na bespartiunoĭ konferentsii rabochikh I krasnoarmeytse v Presnenskogo raĭona 24 ianvarya 1920 g.", Polnoe sobranie sochineniŭ, Vol. 40 (Moskva: Izdatel `stvo politicheskoŭ literaturȳ, 1974), 71.

42 Georgiĭ V. Chicherin, "Lenin i vneshn'aya politika", Izvestiya, 30.01.1924.

43 "Dogovor s Gruziê", Pravda, 09.05.1920.

$44 \quad$ Vladimir I. Lenin, "Politicheskij otchet CK RKP(b) na IX Vserossiyskoy konferencii RKP(b) i zakluchitelnoe slovo po itogam obsuzhdeniya otcheta 22 sentyabrya 1920 g.", V. I. Lenin, Neizvestnȳe dokumentȳ (Moskva: ROSPEN, 2017), 376. 
Thus, the peace treaty with Estonia was indicative of a certain turning point in Soviet politics but not of a departure from the strategic direction developed by the Bolsheviks when they seized power in October of 1917.

\section{The Cold Peace of the 1920 s and 1930 s}

Although the preamble of the Tartu Peace Treaty declared the desire for a just and lasting peace, Soviet-Estonian relations in the 1920 s and 1930 s were extremely fitful with an icy atmosphere prevailing.

Despite occasional flip-flops dictated by short-term interests, Soviet propaganda painted Estonia mainly in dark colours throughout the $1920 \mathrm{~s}$ and 1930s. Soviet ruling circles tended to regard Estonia as being dependent on great powers. In this way, Chicherin considered Estonia's sovereignty fictitious ${ }^{45}$ Discursively similar statements were present in both the propaganda and the academic literature of that period. Thus, the Grand Soviet Encyclopaedia, to which a great deal of scholarly as well as political importance was attached, stated in its article on Estonia that 'the main objective of the fledgling republic was to prove to the great powers of the Entente, to whom its future destiny entirely belonged, its ability to carry out the orders of its masters' ${ }^{46}$ Estonia's relations with the United Kingdom and Poland were of particular concern. The Comintern's reasoning followed along the same lines, so much so that the documents of the II Congress of the Comintern, which took place under Lenin's stewardship just a few months after the Tartu treaty was signed, contended that Estonia, along with a number of other countries of the region, had become fully dependent on the United Kingdom, and that the Baltic Sea had become 'another gulf of Great Britain'. ${ }^{47}$ Fyodor Raskolnikov, the Soviet Ambassador to Estonia from 1930 to 1933 , drew on the formula 'Poland - the master, Estonia - the estate manager', which seemed overly simplistic even to some Soviet diplomats. In early 1931, Raskolnikov reported to Moscow about a likely deployment of troops in Estonia by Poland to back up its offensive on Leningrad. ${ }^{48}$ By

\footnotetext{
$45 \quad$ Evgeniŭ R. Voronin, "Diplomatiya Chicherina kak instrument obespecheniya gosudarstvennȳkh interesov v usloviyakh krizisnogo razvitiya Evropy", Analiticheskiu doklad v MGIMO. 1 (44) (2015), 12.

46 Bolshaya sovetskaya enciklopediya, Vol. 64 (Moskva: OGIZ, 1933), 704.

47 Kommunisticheskiu Internatsional $v$ dokumentakh. Resheniya, tezis $\bar{y} i$ vozzvaniya kongressov Kominterna i plenumov IKKI. 1919-1932 (Moskva: Partizdat, 1933), 140.

48 Aleksandr I. Rupasov F. F., "Raskol’nikov v Estonii (1930-1933). Neskolko shtrikhov $\mathrm{k}$ portretu”, Rossiya $v$ XX veke. Sbornik stateı $k 70$-letiyu so dnya rozhdeniya chlenakorrespondenta RAN Valeriya Aleksandrovicha Shishkina (Sankt Petersburg: NestorIstoriya, 2005), 318, 332.
} 
the latter half of the 1930s, the focus had somewhat shifted towards pointing out the rise in German influence. Soviet propaganda affirmed that the Baltic states could become one of the routes for German aggression against the Soviet Union..$^{49}$ At the same time, German-British contradictions were being overlooked while Estonia's aspiration to be a neutral state was typically presented in an ironic manner by the Soviet press.

Estonia's social-political order was described in similarly negative terms, where democracy supposedly existed only for the elites, whereas workers were brutally exploited, while any manifestation of discontent was ruthlessly crushed. In the mid-1920s, reports on the rise of fascist organisations in Estonia appeared in the Soviet press and popular literature. ${ }^{50}$ In the early 1930s, the leadership of the People's Commissariat for Foreign Affairs, obviously drawing on the Comintern's attitudes of the time, came up with the idea of 'rising fascism' and the 'fascistisation of Estonia', although Raskolnikov took a more cautious stance. ${ }^{51}$

During the interwar period, both trends figured in Soviet policy towards Estonia - a course for world revolution and a desire to build interstate relations.

The course for World Revolution had considerable specificity in relation to Estonia. In the 1920 s and early 1930s, Moscow operated on the assumption that the next country to see communists come to power was Germany. Even in December of 1933 - after Hitler took power - the Comintern continued to insist that Germany was the key to the growing proletarian revolution..$^{52}$ Initially, the Soviet and Comintern leadership predominantly believed that any interaction between the USSR and the German revolutionary movement would have to come through the Baltic countries. In 1923, Soviet diplomats put out feelers to the Latvian ambassador Kārlis Ozols exploring the possibility of the Red Army passing through Latvia to help revolutionary Germany. ${ }^{53}$

The failure of the 'German October' in 1923 was one of the reasons for the Bolsheviks to revise their strategy. In 1924-1925, the Stalinist concept of 'socialism in one country' came to be recognised as the only correct

$49 \quad$ Nikita A. Lomagin, Natalia V. Savinova, “Obraz pribaltijskikh stran v predvoennȳĭ period (1934-1940)”, Obraz drugogo. Strani Baltii i Sovetskiı̆ Soyz pered Vtorŏ mirovŏ voinoŭ (Moskva, Rosspen, 2012), 178-179.

50 Karsten Brüggemann, "Obraz Pribaltiki v rannem sovetskim stranovedenii: starȳe stereotipȳ i novȳe obrazȳ vragov", Rossiya i pribaltiǔskiŭ region v XIX-XX vv.: Problemȳ vzaimootnosheniı̌ v menyayushemsya mire (Moskva, 2012), 55.

51 Rupasov F. F., "Raskol 'nikov v Estonii (1930-1933)", 323.

52 XIII Plenum IKKI. Stenograficheskij otchet (Moskva, Partizdat, 1934), 2, 37.

53 Karlis Ozols, Memuary poslannika (Moskva: Centrpoligraf, 2015), 171-172. 
path, while the world revolution began to be seen not as a one-off act, but as a gradual process of one country after another breaking away from the capitalist system. The role of 'the pillar of liberation of the workers in capitalist countries from the yoke of the bourgeoisie' was assigned to the Red Army. ${ }^{54}$ According to Boris Naydenko, the main aim of Soviet military policies towards the Baltic states in the 1920s-1930s was the reestablishment of control over this region by the restoration of Soviet power. At the same time, Soviet policies were two-faced: on the one hand they appeared pragmatic, but on the other they were oriented towards the idea that any future war in the region would turn from an imperialist war into a civil one. ${ }^{55}$

In December of 1924, a communist coup was attempted in Estonia, ending in failure. There are discussions among historians (Valge, ${ }^{56}$ Mikhajlova and Roginskij ${ }^{57}$ ) on some aspects of the preparations for the revolt and the role of Comintern and Estonian communists, but there is no doubt that the revolt was planned with the approval of the Soviet leadership ${ }^{58}$ which was contrary to the obligations of the 1920 peace treaty. Only a few Russian historians (Tsyplin ${ }^{59}$ ) now deny the role of the Comintern and express doubts regarding Soviet involvement in preparations for the communist coup. However, after the fiasco, Moscow sought to avoid exacerbating interstate relations with Estonia. So, for instance, although the communists who had fled to the USSR by plane were granted political asylum, the aircraft itself was returned to Estonia. ${ }^{60}$ Consequently, the Communist Party of Estonia, the influence of which had dropped off to a minimum as a result, was not taken seriously in Moscow. Suffice it to note that Comintern documents from the late 1920s and the 1930s barely ever mentioned it. After the 1924 debacle, an understanding that Estonia possessed no revolutionary potential

\footnotetext{
54 “Na shturm kapitalizma, k mirivoŭ Kommune’. Stenogramma doklada L. Z. Mekhlisa na sobranii partiı̆nogo aktiva Kievskogo osobogo vojennogo okruga 4 aprelya 1939 goda", Istoricheskil arkhiv, 2 (2005), 87.

${ }_{55}$ Boris N. Naĭdenko, Voennaya politika Sovetskogo gosudarstva $v$ otnoshenii stran Pribaltiǔskogo regiona i Polshi, 1918-1940 gg. (Moskva, PhD thesis, 2001), 318. https:// search.rsl.ru/ru/record/01000337025 (20 November 2020).

56 Jaak Valge, "Podgotovka Sovetskim Sojuzom gosudarstvennogo perevorota v Estonii v 1924 g.", Peterburgskiu istoricheskiǔ zhurnal, 1 (2015), 183-201.

57 Iuliya L. Mikhailova, Vadim V. Roginski1̌, "Mirovaya revolutsiya ostanovlena v Talline? 1 dekabrya 1924 g.", Rossiya i pribaltiǔskiŭ region v XIX-XX vv.: Problemy vzaimootnosheniǔ v menyayushemsya mire (Moskva, 2012).

58 Politburo CK RKP(b)-VKP(b) i Komintern (Moskva, 2004), 273.

59 Vitalij G. Tsȳplin, "Sovetsko-estonskie otnoshenia v seredine 1920-kh godov", Izvestia Saratovskogo Universiteta, Seria Istoria, Mezhdunarodnȳe otnoshenie. Vol, 16, 2 (2016), 149.

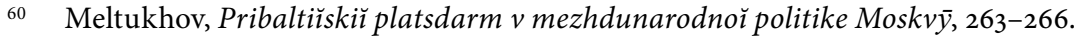


most likely became deeply entrenched in the mind-sets of the Soviet and Comintern leaders. At any rate, there is no evidence that Moscow made any practical efforts to stage a new armed communist uprising in the span between 1925 and 1939. Nevertheless, the plans to use the territory of the Baltic states to launch an offensive by the Red Army had been kept alive. When the German and Polish communist press published an article in the early 1930s on the possibility of the Red Army invading Estonia and several other states in case of war between the Soviet Union and capitalist countries, Moscow was very worried that these publications revealed Soviet plans to the enemy. ${ }^{61}$

In the latter half of the 1930s, the Comintern changed its tactics. The VII Congress (1935) urged the establishment of popular fronts against the threat of war and fascism, and called for the coming to power of 'Workers' and Peasants' governments', which would lead their countries to socialist revolutions and the establishment of Soviet power. ${ }^{62}$ French communists even developed a specific plan of action. Their leader Maurice Thorez argued that with the coming to power of a 'Workers' and Peasants' government', the state in its present form would be overturned and replaced by Soviet Councils, taking over all legislative and executive power. There would be no 'Senate', while the 'Chamber' of Parliament would be replaced by the Executive Committee of the Soviets of People's Representatives (it is noteworthy that the words 'Senate' and 'Chamber' were set in quotation marks by Thorez, clearly indicating his contemptuous attitude towards them). This would be followed by a transition to socialist construction in France. ${ }^{63} \mathrm{~A}$ scenario closely resembling what Thorez envisioned was realised in Estonia in 1940. One should note that the absence of communists in the Estonian government from June to August of 1940 was fully in line with the decisions of the VII Comintern Congress, which stated that the participation of communists in such governments was a matter of political expediency rather than principle. ${ }^{64}$

Interstate relations between the USSR and Estonia throughout the $1920 \mathrm{~s}$ and 1930s were generally quite cold. Immediately after the signing of the peace treaty, both parties took steps to normalise and develop their relations.

${ }_{61}$ Komintern i ideya mirovoy revolutsii. Dokument $\bar{y}$ (Moskva, Nauka, 1998), 760-764.

62 VII kongress Kommunisticheskogo Internatsionala i bor' ba protiv fashizma i voiny. Sbornik dokumentov (Moskva: Politizdat, 1975), 144-146, 171.

63 Moris Torez, Sovremennaya Frantsiya i Narodnȳĭ front (Moskva: Sotsekonomgiz, 1937), 123-126.

${ }_{64}$ VII kongress Kommunisticheskogo Internatsionala i bor' ba protiv fashizma i voìny, 206. 
Diplomatic ties were officially established, and an exchange of ambassadors took place. Maxim Litvinov, a well-known Bolshevik, was appointed as the Soviet representative (including trade) to Tallinn. This indicated the importance that Moscow attached at that time to its relations with Estonia. Shortly after the signing of the peace treaty, a trade delegation from Soviet Russia arrived in Estonia, while their counterparts went to Russia. Estonia was important to Soviet Russia not only as its sole legal trading partner, but also as a legal trade channel to other countries. Soon, however, its role diminished as the Soviet government gained recognition from the largest European countries during the first half of the 1920s. In the early 1920s, Soviet Russia and Estonia signed agreements on refugees, opting procedures regarding citizenship, passenger, freight, and rail traffic, postal, telegraph and telephone communications, etc. The Soviet government greatly appreciated Estonia's food aid to the starving population of Russia. ${ }^{65}$

Soon, however, a trend towards cooling down took over in Soviet-Estonian relations. This was not just a matter of antagonism between two sociopolitical systems. First and foremost, the USSR was wedded to the idea of the inevitability of war against the capitalist world, and so every state along the border with the West was viewed as a potential adversary. Of all the Baltic states, Estonia was seen by Moscow as the most likely to have close relations firstly with Great Britain, which during the 1920 and 1930 os was regarded as the most adversarial power towards the Soviet Union, secondly with Poland (once in a while Moscow would come to believe that there existed a secret pact between Warsaw and Tallinn), and thirdly, starting from the latter half of the 1930s, with Germany. What added fuel to those sentiments was that according to Soviet information, it was Tallinn that was the main British intelligence centre in the Baltic Sea region. However, as the historian Aleksandr Rupasov rightly noted, one of the most important reasons for such an attitude towards Estonia was that 'Soviet diplomacy in fact had no leverage over Tallinn on a whole range of issues of interest to Moscow'. ${ }^{66}$ Estonia, in turn, believed that the main threat to its security came from the USSR. In and of itself, this created a specific context for their bilateral relations.

In addition, the USSR focused mainly on its relations with great powers, viewing relations with Estonia and the other Baltic states as secondary. Estonia, in turn, prioritised relations with the countries of Western

\footnotetext{
65 Serger A. Tambi, "K 10o-letiyu ustanovleniya diplomaticheskikh otnosheniŭ mezhdu Rossieĭ i Estonieî”, Mezhdunarodnaya zhizn', 7 (2020), 46-67.

66 Aleksandr I. Rupasov, "Sovetsko-estonskie otnosheniya v period mirovogo ekonomicheskogo krizisa", Peterburgskiŭ istoricheskiŭ zhurnal, 3 (2016), 130.
} 
and Northern Europe over those with the USSR. At the same time, neither side did anything to dispel the negative attitude of its neighbour. In the 1920 and 1930s, the Soviet press would sometimes use the term beloestoncy (White Estonians). Although its usage was less frequent than that of belofinny (White Finns) or belopolyaki (White Poles), the connotation was just as pejorative. Even more contradictory was the appointment of Ambassador Raskolnikov. He had been regarded as a truly odious figure in Estonia ever since the events of 1918-1919 (he was the commander of the Soviet Baltic Fleet during the unsuccessful attempt to attack Tallinn in December of 1918 and was on the list of communist candidates for the election of the Constituent Assembly in 1919). So Tallinn consented to his appointment only following strong pressure from the USSR. ${ }^{67}$ In his capacity as ambassador, he permitted himself disparaging remarks about his host country and was socially ignored by Estonian political and business elites, as well as by foreign diplomats. It is remarkable that throughout the almost 20 years of their relations, neither of the countries initiated any major cooperation project in any field. At the same time, until the outbreak of World War II, both the Soviet Union and Estonia had tried to keep their variances within certain bounds, avoiding major crises. A manifestation of this tendency was their signing of the 1932 Non-Aggression and Peaceful Settlement of Conflicts Treaty, along with a few other agreements.

Soviet diplomacy often tried to drive a wedge between its Western neighbours to prevent their rapprochement, particularly between Poland and Estonia. Thus in 1930, the Politburo of the Central Committee of the AllUnion Communist Party (Bolsheviks) approved an invitation to Estonia's Foreign Minister Jaan Lattik to visit the Soviet Union prior to his meeting with Polish leaders (that visit never took place). ${ }^{68}$ At the same time, Moscow was well aware that it had practically no chance of influencing PolishEstonian relations, but also that Tallinn was trying to develop relations with other countries in such a way as to avoid aggravating its relations with the USSR. Estonia's close relations with Poland and to some extent with Finland were one of the main reasons why the USSR had far fewer military contacts with Estonia than with either Lithuania or Latvia. In fact, there were only a few official visits and the regular activities of military attachés, which were mostly ceremonial. In January of 1934, the Politburo decided to invite military delegations from Lithuania and Latvia to the USSR, but

$67 \quad$ Rupasov F. F., ”Raskol 'nikov v Estonii (1930-1933)", 312.

68 Oleg N. Ken, Aleksandr I. Rupasov, Zapadnoeprigranich 'e. Politburo CK VKP $(b)$ i otnosheniya s zapadnȳmi sosednimi gosudarstvami. 1928-1934 (Moskva: Algoritm, 2014), 171. 
not from Estonia.$^{69}$ In 1936, General Nikolai Reek visited Moscow and in February of 1937, Marshal Aleksey Yegorov was in Tallinn, but neither visit produced any practical results. ${ }^{70}$

The USSR had grave concerns about the possibility of an alignment of newly independent countries forming along its north-western borders. Politicians and journalists in those countries repeatedly discussed this idea, but no practical steps ensued, mainly due to disagreements between the prospective participants (Lithuania, Poland, and others). The agreement on cooperation between Estonia, Latvia, and Lithuania ('the Baltic Entente') also proved ineffective - even when tensions were running particularly high, namely between 1939 and 1940, all three countries not only failed to assist each other but never even tried to coordinate their actions. Moscow's fears in this regard were clearly exaggerated, however, they did have an impact on Soviet decision-making.

Trade and economic relations with Estonia appeared crucial for the Soviet state in the early 1920s. At the initial stage, the USSR actively used Estonia as a transit country and as an intermediary when dealing with countries that it had no official relations with. Later, as trade relations with other countries were being normalised, the importance of Estonia's role gradually diminished. This was mainly due to the distinct discrepancy between the two models of foreign trade. Because of the state monopoly on foreign trade in the USSR, many Estonians feared that trade deals would be used for not only economic but also political purposes. The USSR, on the contrary, feared that private foreign capital would try to undermine the state monopoly on foreign trade, establishing direct contacts with Russian entrepreneurs, whose activity had come alive somewhat as a result of the New Economic Policy. What made things worse was the USSR's constant shortage of hard currency and the Estonian public's suspicion regarding any contacts with Soviet citizens, especially after the attempted communist revolt of 1924. Now and then, disputes would arise between the USSR and Estonia, yet they never escalated into open conflicts. There were occasional calls within the Soviet government for changing Estonia's attitude by offering it a number of economic benefits. However, those proposals were invariably rejected.1

\footnotetext{
$69 \quad$ Politburo CK RKP(b) - VKP(b) i Evropa. Resheniya "osobor papki”. 1923-1939 (Moskva: Rosspen., 2001), 308.

70 Albert P. Nenarokov, Vernost dolgu: o marshale Sovetskogo Sojuza I. A. Jegorove (Moskva: Politizdat, 1989), https://www.litmir.me/br/?b=197104\&p=1 (20 November 2020).

71 Ken, Rupasov, Zapadnoeprigranich 'e, 154-155.
} 
The Soviet leadership recognised that there were no social strata or political forces in Estonia that they could rely on. For that reason, Moscow latched on to pronouncements of any Estonian politicians on the need to industrialise the country, hoping that it would lead to greater numbers of the proletariat, which was considered the vanguard of revolution. The speech given by the Estonian Minister of Finance Anton Teetsov in February of 1928 attracted particular attention, and Soviet diplomats in Tallinn were instructed to support this line ${ }^{72}$ Raskolnikov and some other Soviet diplomats were very enthusiastic regarding the perspectives for Estonian industrialisation, but in the early 1930s Moscow's attitude towards this idea became more sceptical. ${ }^{73}$ Because Estonia's industrialisation remained limited, the USSR placed all its stakes on building a network of individuals across various social strata who had some connection to Moscow or were outright Soviet agents. It would be difficult to evaluate the effectiveness of that network unless all Soviet archives were opened, but the fact that it was quite extensive is beyond doubt.

The signing of the Soviet-German Non-Aggression Pact of 23 August 1939 and the Treaty of Friendship and Borders of 28 September 1939, each of which was accompanied by secret protocols, was a violation by the USSR of its obligations to Estonia under the 1920 peace treaty and the 1932 Treaty of Non-Aggression and Peaceful Settlement of Disputes. It should be emphasised that until the establishment of the United Nations, the Soviet approach to international law was qualitatively different from what was generally accepted. The view prevailed among the Soviet ruling class that the position of the USSR did not come down to 'the indiscriminate denial of all norms of international law', nor did it imply 'the application of all such norms without exception'. In this vein, the USSR proceeded exclusively from 'the interest of ensuring its own security and international peace in both political and economic relations' ${ }^{74}$ Such an interpretation of international law allowed the broadest possible room for manoeuvring and for renouncing any previously assumed commitments. For this reason, from the Soviet point of view, the treaties with Germany concurred with their understanding of international law.

Thus, the compromise reached in February of 1920 in Tartu had been in effect for two decades. During that period, the USSR's trajectory of development and that of Estonia diverged significantly, while their treatment of

72 Rupasov, "Sovetsko-estonskie otnosheniya v period mirovogo ekonomicheskogo krizisa”, 108.

73 Rupasov F. F., "Raskol 'nikov v Estonii (1930-1933)", 316.

74 Bolshaya sovetskaya entsiklopediya, Vol. 46 (Moskva: Ogiz, 1940), 642. 
each other underwent significant changes. The model of socio-economic development that was being established in the USSR from the 1920s through the 1930 s was completely opposite to the one in Estonia. The Bolsheviks were convinced that their model was superior and that it would triumph all over the world, including in Estonia. Yet it triggered nothing but rejection in Estonia, except with the far left. Due to their antagonism, it was largely impossible to harmonise the two systems, therefore difficulties and friction would constantly arise between the two countries.

Furthermore, after the initial momentum that resulted from the peace treaty of 1920, for various reasons, neither party preserved its interest in further cooperation. The Bolsheviks never abandoned their plans for Sovietising Estonia, viewing it as a strategic matter, since they believed that it was inevitable that war would break out between the USSR and the capitalist countries. All other possible areas of cooperation, including economic relations, gradually faded into the background. As a small state, Estonia found it very difficult to develop its own policy towards the neighbouring great power. It seems that Estonia's ruling elites did not fully comprehend the magnitude of the deteriorating political environment in Europe, especially in the latter half of the 1930s, and did not always take into account Moscow's likely interpretation of their steps in the international arena. Estonia's policy towards the USSR was rather reactive. Nevertheless, peaceful coexistence of the two countries could have possibly continued had it not been for the Second World War.

\section{A Century Later: The Tartu Peace Treaty and the Present}

Evaluations of the Tartu Peace Treaty have been a matter of heated debate thus far, involving not only academics but also politicians, diplomats, journalists, and the general public. The official positions of Estonia and Russia have been diametrically opposed, and there is a reason for it. From 1989 to 1991, Russia and Estonia were in concert in opposing the Union's centre, and it seemed to many that they would choose similar models of social development in the future as well. However, that was not the case - Russia followed the path of state, authoritarian capitalism (the establishment in Moscow are convinced that this model is superior), ${ }^{75}$ whereas Estonia

\footnotetext{
75 Sergey A. Karaganov, "Russkaya otchayannost' osedlala volnu istorii”, Russia in Global Affairs, <http://globalaffairs.ru/pubcol/Russkaya-otchayannost-osedlala-volnuistorii-19180> (20 November 2020); Sergey A. Karaganov, "A New Epoch of Confrontation", Russia in Global Affairs, <http://eng.globalaffairs.ru/number/A-New-EpochofConfrontation-19433> (20 November 2020).
} 
chose the path of liberal democracy. The differences between the two are not as antagonistic as between communism and capitalism but they inevitably lead to friction and variances. How much of that rises to the surface depends largely on the policies of both countries.

Estonia's official position is that the Estonian state was established by the Manifest Eestimaa rahvastele of 1918 and by the Tartu Peace Treaty of 1920; from 1940 to 1991 it was under foreign occupation (sometimes also referred to as the Soviet annexation of Estonia), and on 20 August 1991, by adopting a resolution on Estonian state independence, the Supreme Council of Estonia reaffirmed the independence of the republic. This implies that modern-day Estonia is not a new state but a continuation of the Republic of Estonia which was proclaimed in 1918. Moreover, it is argued that the peace treaty of 1920 is still in force today. As President Kersti Kaljulaid said: 'The Tartu Peace Treaty was, is, and will always remain the birth certificate of the Estonian state. And it is valid'. ${ }^{76}$ Russia's official position is that 'the Tartu Peace Treaty has long been a part of history. Like other international agreements that Estonia used to have, including those with Soviet Russia between 1920 and 1940, it ceased to be in effect on 6 August 1940, when Estonia became part of the USSR. For us, this topic is off the table'.77 Some Russian researchers like Vadim Musaev even cast serious doubt on the Estonian argument that the Tartu Peace Treaty was concluded within the framework of international law because at the moment of its signing, both states were not recognised by anybody else. ${ }^{78}$ As we see it, there seems to be some weaknesses and inconsistencies in the arguments of both sides.

First of all, it should be pointed out that the legal framework of modern Russian-Estonian relations uses a number of circuitous and imprecise formulations. In 1991, Russia and Estonia concluded the Treaty on Basic Principles of Interstate Relations, which was ratified and entered into force after

$76 \quad$ President Kaljulaid: 'the Tartu Peace Treaty was, is and will always remain the birth certificate of the Estonian state': "President Kaljulaid: the Tartu Peace Treaty was, is and will always remain the birth certificate of the Estonian state", Official Press Release, 2 February 2020, <https://www.president.ee/en/meedia/press-releases/15798-presidentkaljulaid-on-the-1ooth-anniversary-of-the-tartu-peace-treaty-the-tartu-peace-treatywas-is-and-will-always-remain-the-birth-certificate-of-the-estonian-state/index.html> (13 May 2020)

77 "Otvet oficialnogo predstavitelya MID Rossii M. V. Zakharovoŭ na vopros SMI otnositel 'no zajavleniı̌ v Estonii o "territorial 'nykh pretenziyakh" k Rossii", the Ministry of Foreign Affairs of the Russian Federation, <https:/www.mid.ru/ru/maps/ee/-/ asset_publisher/mo1LgbIkJbRf/content/id/3648750> (13 May 2020)

78 Sergej Glezerov, “"Ustupka na veki”. Kak zakluchali Tartuskiĭ dogovor”, SanktPeterburgskie vedomosti, 26 fevralya 2020 , https://spbvedomosti.ru/news/nasledie/ ustupka-ne-naveki-kak-zaklyuchali-tartuskiy-dogovor/ (20 November 2020). 


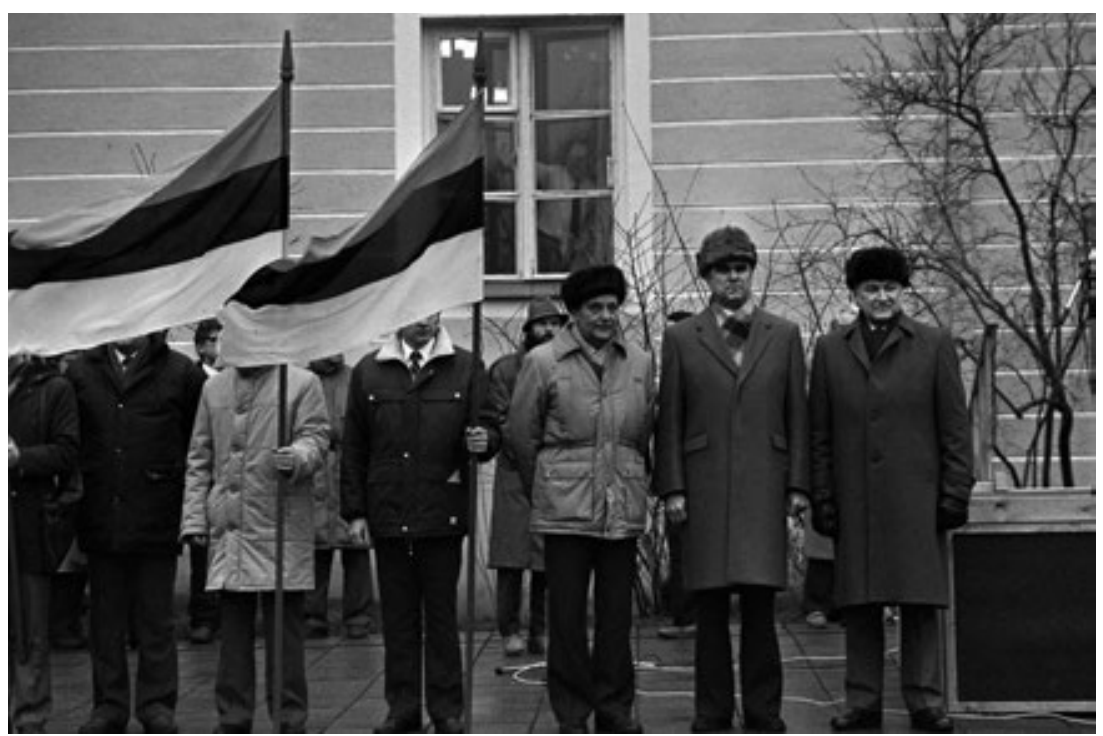

Figure 2. Celebrating 70-year-anniversary of the Tartu Peace Treaty, February 2, 1990. From right: Chairman of the Supreme Soviet of the Estonian Soviet Socialist Republic Arnold Rüütel, Head of the Council of Ministers of the Estonian Soviet Socialist Republic Indrek Toome, First Secretary of the Central Committee of the Communist Party of Estonian Soviet Socialist Republic Vaino Väljas. Image: Erich Tarkpea. RA, EFA.204.0.169152

the collapse of the USSR. It stated that both parties were guided by the decisions on the state status of the parties that were adopted by the Congress of People's Deputies of the RSFSR on 12 June 1990 and by the Supreme Soviet of Estonia on 30 March and 7 August 1990. Thus, the doctrine of state continuity proclaimed by the Estonian side was indirectly recognised because the Tartu Peace Treaty is also mentioned in those documents. At the same time, one can hardly overlook the fact that quite a few provisions of the 1991 treaty, especially those on security, political, economic, and humanitarian relations, lay down rules and norms that differ entirely from those of the 1920 treaty. Particularly noteworthy is Article VI of the 1991 treaty, which does not refer to a return to the borders of 1920 , but rather to the fact that both parties 'respect each other's right to territorial integrity in accordance with the principles of the Conference on Security and Cooperation in Europe, and will conclude a separate treaty on the state border regimen'. ${ }^{79}$

79 Dogovor ob osnovakh mezhgosudarstvennȳkh otnosheniǔ Rossiǔskoŭ Sovetskoŭ Federativnoı̆ Sotsialisticheskoĭ Respubliki i Estonskoŭ Respubliki, Ofitsial'nȳı̆ 
The events of 1939-1940 also demand more comprehensive scrutiny. The results of the Riigivolikogu elections in Estonia on 14-15 July 1940 can hardly be considered justification for the incorporation of Estonia into the USSR, as they were held in violation of Estonia's 1938 Constitution. The same can be said about the laws adopted by the Riigivolikogu, which were not approved by the Riiginõukogu. The upper house - the Riiginõukogu was disbanded immediately after the establishment of the 'people's government', exactly as the Thorez scheme envisaged. There are several opinions among Russian researchers on the events in the Baltic states in 1940 - from full justification of Soviet politics to calling them an act of annexation. ${ }^{80}$

The evolution of elections in July of 1940 is also different. Few Russian scholars now defend the argument that the elections of 14-15 July 1940, and the events that followed, were legitimate..$^{81}$ Most of them either point out that they were indeed held, giving no further evaluation, ${ }^{82}$ or recognise, as Dyukov does, that 'we cannot say exactly what the will of the people was'. ${ }^{83}$ Some researchers admit that the 1938 Estonian Constitution was violated. ${ }^{84}$ It seems that 'Sovietisation' would be the most accurate definition for the events of 1940 since the essence of the process was not just the incorporation of Estonia into the USSR, but a complete replacement of its socio-economic system by another one based on diametrically opposite principles and values. ${ }^{85}$ But Sovietisation was not voluntary, nor did it receive the support of the majority of people in any country, including Russia. A critical evaluation of the 1940 elections, however, does not do away with the question raised by a number of scholars (Ilmjärv, ${ }^{86}$ Kasekamp $^{87}$ ) as to whether the Estonian ruling circles also share some responsibility for what happened.

\footnotetext{
internet-portal pravovoŭ informatsii, $</ /$ http://pravo.gov.ru/proxy/ips/?doc_itself=\&co llection $=1 \&$ nd $=203003572$ \&page $=1 \& \mathrm{rdk}=0 \&$ link_id=6\#Io $>(13$ May 2020)

80 Yuliya Z. Kantor, Pribaltika: voina be zpravil (1939-1945) (SanktPeterburg: Zvezda, 2011), 70.

81 Oleg A. Zimarin, "Istoriya stran Baltii v ocherkakh Andresa Kazekampa i Andreǐsa Plakansa”, Rossiya i Baltiya, 7 (2015), 212-213.

82 History of International Relations and Russian Foreign Policy in the $20^{\text {th }}$ Century, ed. by A. Torkunov. Vol. 1 (Cambridge Scholars Publishing, 2020), 250.

83 "Sporȳ ob anneksii: kogda Rossiya i Estoniya ratifitsiruyut dogovor o granitse", Deutsche Welle, 9 December 2019.

84 Elena Yu. Zubkova, Pribaltikai Kreml' 1940-1953 (Moskva: Rospen, 2008), 85-87.

85 Konstantin K. Khudoley, "Sovetizatsiya Baltiǔskikh gosudarstv letom 1940 g. i eё posledstviya”, Vestnik Sankt Peterburgskogo universiteta, 1 (2013), 94-110.

86 Margus Ilmjarv, Silent Submission: Formation of Foreign Policy of Estonia, Latvia \& Lithuania: Period from Mid-1920-s to Annexation in 1940 (Stockholm, 2004).

87 Andres Kasekamp, A History of the Baltic states (New York: Palgrave Macmillan, 2010), 127.
} 
The reaction of the international community towards the incorporation of Estonia and the other two Baltic states into the USSR was not so unequivocal either. Most Western democracies never accepted it. Despite every attempt by Moscow, the clause recognising the Soviet Union within its 1941 borders was not included in either the Allied Treaty of 1942 with Great Britain or in that of 1944 with France. At the 1943 Tehran Summit, Roosevelt put the question of the future of Estonia, Latvia, and Lithuania to Stalin, who promised that the Baltic peoples would have the chance to express their will. Both leaders spoke about elections or a plebiscite without international controls, but in very general terms. ${ }^{88}$

Thereafter, the question was removed from the agenda of international negotiations for a while. Yet only the Netherlands, Spain and New Zealand recognised Estonia, Latvia and Lithuania as part of the USSR de jure, whereas a few other countries went on to settle financial issues without de jure recognition. ${ }^{89}$ Before signing the Final Act of the Conference on Security and Cooperation in Europe in 1975, US President Gerald Ford said that the signing did not imply that Estonia, Latvia and Lithuania were recognised as parts of the USSR..$^{90}$ At the time, no official response from the USSR followed that statement. Still, the incorporation of Estonia, Latvia and Lithuania into the USSR was recognised by the Communist Bloc countries and by a number of Asian and African states. None of them expressed any reservations about the Baltic states when establishing diplomatic relations with the USSR. At the same time, the West's refusal to recognise the incorporation undoubtedly had a certain influence on Moscow's policy. Along with the resistance of the peoples of Estonia, Latvia and Lithuania to Sovietisation, this consequently probably played an important role when, instead of insisting on the Soviet system, Stalin opted for a softer form of communist rule, namely 'people's democracy', in Central and Eastern Europe after World War II. It even seems that Stalin used some ideas from the Baltic left, which he had rejected in the $1940 \mathrm{os},{ }^{91}$ for the

\footnotetext{
$88 \quad$ Tegeranskaya konferentsiya rukovoditeleŭ trëkh soyuznȳkh derzhav SSSR, SSHA $i$ Velikobritanii (28 noyabrya - 1 dekabrya 1943 g.). Sbornik dokumentov (Moskva: Poliizdat, 1993), 151-152.

89 Konstantin K. Khudoley, 'Soviet Foreign Policy During the Cold War: The Baltic Factor', The Baltic Question during the Cold War, ed. by John Hiden, Vahur Made, David J. Smith (Routledge, 2008), 56-72.

90 Gerald R. Ford, Public Papers of the President of the United States. Containing public messages, speeches, statements of the president, 1975. Book II. 21 July to 31 December 1975 (Washington, 1975), 430.

${ }_{91}$ Iz vospominaniy Yuozasa Vaysporosa o beside A. Ja. Wyshynskim v Moskve ot 8.o9.1940, SSSR i Litva v godi Vtoroy Mirovoy Voyni. Vol. 1, SSSR i Litovskaya Respublika (mart 1939
} 
'people's democracy'. However, Stalin is not known to have recommended the repetition of the experience of the Sovietisation of the Baltic states to any communist leader in Central and Eastern Europe.

Although it would be difficult, it would not be impossible to come to a mutually acceptable solution, provided that both sides have the requisite political will. This was the case in the autumn of 1991, when both parties agreed to be in diplomatic relations. A possible compromise could be to declare respect for Article II of the Tartu Peace Treaty as a way of acknowledging the 'birth certificate' of Estonian independence, provided that there would be mutual agreement that all other issues would be resolved in accordance with the realities of the $21^{\text {st }}$ century. At present, however, the likelihood of reaching a compromise is minimal. The trauma suffered by the Estonian ruling circles and the whole of society as a result of the events of 1939-1940 has not been healed yet. By emphasising the importance of the Tartu Peace Treaty, Estonia seeks to show once again the illegality of its incorporation into the USSR. For the higher strata of society in Russia, who in many ways consciously or instinctively consider themselves to be the successors and continuators of the Soviet nomenclature, the collapse of the Soviet Union is associated with their greatest trauma. Therefore, by denying the validity of the Tartu Peace Treaty today, they first and foremost try to justify Soviet policy. It must be added that in light of the ongoing 'Cool War' between Russia and the West, which started in 2014, the level of trust between Russia and Estonia has plummeted sharply.

This, however, does not mean that some concrete steps cannot already be taken now to improve relations. First of all, this refers to the border treaty. It has already been signed twice but then suspended at the ratification stage. Objectively speaking, it is in the interests of both sides for it to finally come into force, and it would be insensible to tie it to the settlement of other issues.

More vibrant relations in the areas of the economy, culture, education, science, cross-border cooperation, youth exchanges, etc. could play out positively in improving Russian-Estonian relations. As of now, they have been drastically reduced due to the corona virus, but their restoration and development is quite possible in the future. Despite the current sanctions and countersanctions, propaganda campaigns and other obstacles, there are many more opportunities for improving relations now than there were in the 1920 s and 1930s.

- avgust 1940). Sbornik dokumenotov (Vilnus: Institut Istorii Litvi. Institut vseobshě istorii Rossiǔskoŭ Akademii Nauk, 2006), 721. 
Thus, the legacy of the past is creating a negative environment for the development of Russian-Estonian relations today. Apparently, one of the main factors that could contribute to improvement would be greater convergence to evaluate, or at least to give up a confrontational approach to, the most complex and controversial events of the past. Of course, one can imagine that with a generational change, the narratives that are now perceived as traumatising will gradually lose their acuteness. Yet one cannot expect that it will occur naturally, even over the long term. Therefore, political will is needed on both sides of the aisle to make it happen.

\section{Conclusion}

The modern world is qualitatively different from what it was just a century ago. It has become much more interconnected in every aspect. Information technology has taken it to a whole new level. It has had a huge impact on international relations, but that does not mean that historical legacies should be ignored or downplayed. The same is true for the Soviet-Estonian Tartu Peace Treaty of 1920.

It seems that in the current context, the most relevant and important way out would be to adopt a methodology similar to the one used a century ago. Back then, it was the first time that a large power and a small country with antagonistic social systems were able to find a mutually acceptable solution which benefited them both - Estonia obtained the initial international recognition of its independence, while Soviet Russia broke through international isolation. The lesson of the Tartu Treaty also demonstrated that success was possible if both sides treated each other with respect and avoided actions that would be unacceptable to the other. It is important to underline that neither side felt humiliated or unfairly treated. Those principles of the 1920 treaty can be used to improve Russian-Estonian relations today. Last but not least, the experience of the events of a century ago showed that the improvement of relations between Russia and Estonia was possible only if a trend towards normalisation rather than confrontation prevailed in relations between Russia and the West as a whole. This is undoubtedly as relevant today as ever.

KeYwords: Tartu Peace Treaty (1920); Estonia; Russia; USSR; peaceful coexistence; world revolution. 
Konstantin Khudoley is Professor and head of the European Studies Department, School of International Relations, St Petersburg State University, Russia.*

KоккUVÕTE: Tartu rahuleping ja selle järelmõjud: Vene-Eesti kokkuleppe käsitlusi tänapäeva Venemaal

Artikkel käsitleb rahvusvahelisi suhteid Esimese maailmasõja järel, keskendudes 1920. aastal Nõukogude Venemaa ja Eesti Vabariigi vahel sõlmitud Tartu rahulepingule, mis tähistas iseseisva Eesti riigi sündi. Tegemist oli esimese leppega, mis sõlmitud väikese kapitalistliku ja suure sotsialistliku riigi vahel. Ühtlasi sümboliseeris see muutust Nõukogude Venemaa poliitikas, olles peaprooviks Venemaa ja Lääne-Euroopa riikide suhete normaliseerumisele. Erinevate sotsiaal-majanduslike mudelite ja vastastikkuse usaldamatuse tõttu ei suutnud leping tagada ka 1920.-30. aastatel lópuni rahumeelset koostööd kahe riigi vahel.

Tartu rahu on jäänud siiani äärmiselt lõhestavaks küsimuseks. Vastakate arvamuste peamiseks põhjuseks on asjaolu, et pärast Nõukogude Liidu lagunemist arenesid Venemaa ja Eesti ühiskondlikult ja majanduslikult väga erinevates suundades. Pinged ja eriarvamused ei välista siiski võimalust leida vaidlusalustes küsimustes lahendusi. Kõige olulisem neist on piirileppe sõlmimine. Tartu rahulepingu sõlmimisel tehtud kompromissid võivad aidata lahendada ka kaasaegseid probleeme Venemaa ja Eesti vahelistes suhetes.

MärksõNAD: Tartu rahuleping; Eesti; Venemaa; Nõukogude Liit; rahulik kooseksisteerimine; maailmarevolutsioon

Konstantin Khudoley on Peterburi Riikliku Ülikooli rahvusvaheliste suhete kooli professor ja Euroopa õpingute osakonna juhataja.*

* Correspondence: Universitetskaya nab. 7-9, St Petersburg State University, School of International Relations, St Petersburg, 199 034, Russia.

* Kirjavahetus: Universitetskaya nab. 7-9, St Petersburg State University, School of International Relations, St Petersburg, 199 034, Russia. 